Jolanta Wnęk

Koło Naukowe „Bibliolog”

Uniwersytet Pedagogiczny w Krakowie

\title{
Współczesne polskie budownictwo biblioteczne na przykładzie gmachów bibliotek w Połańcu i Myślenicach
}

W ostatnich latach coraz więcej słyszy się o modernizacjach i powstawaniu nowych budynków bibliotek publicznych w Polsce. Przedsięwzięcia te finansowane są głównie przez Unię Europejską. Fakt ten bardzo cieszy, ponieważ w Polsce remonty budynków instytucji kulturowych wykonywane są przede wszystkim przy jubileuszach lub wydarzeniach politycznych, a dzięki dotacjom z Unii można je wykonywać bez specjalnych okazji. Motorem tych działań jest potrzeba szeroko rozumianego rozwoju kulturalnego społeczeństwa, dbanie o dorobek pisarski oraz dorównywanie krajom lepiej rozwiniętym pod względem technicznym.

Lucjan Biliński twierdzi, że ,pomimo niesprzyjającej sytuacji dla inwestycji bibliotecznych (trwającej przez cały okres PRL i odbudowy Rzeczpospolitej) głównie z braku środków finansowych na ten cel, posiadamy liczący się dorobek teoretyczny i praktyczny w dziedzinie budownictwa bibliotecznego"1. Ciągle poszerza się liczba architektów projektujących budynki biblioteczne, które są bardziej funkcjonalne i intrygują wyglądem. Ważne jest, aby już przy projektowaniu budynku kierować się tym, że ma być on przede wszystkim funkcjonalny.

$\mathrm{Na}$ temat projektowania gmachów bibliotecznych wypowiedział się w 1980 r. Zbigniew Cudnik:

Zakładając, że nowy gmach biblioteki ma służyć ludziom przez całe wieki, jego przystosowalność do zmian jest sprawą zasadniczą, pierwszoplanową. Powinien on odpowiadać aktualnym potrzebom, ale i posiadać cechy, które sprostałyby zmieniającym się wymaganiom; aby dzisiejszy magazyn czy czytelnie mogły stać się jutro pracowniami bibliotecznymi, salami konferencyjnymi, pomieszczeniami na seminaria dla studentów audytoriami. [...] Już przy pro-

${ }^{1}$ Biliński L.: Nowe obiekty bibliotek publicznych $w$ Polsce. W: Biblioteki jutra: nowa perspektywa organizacji przestrzennej i funkcjonalnej. [Red. meryt.: Jadwiga Chruścińska, Ewa Kubisz]. Warszawa: CEBID, 2001, s. 46. 
jektowaniu budynku biblioteki należy wziąć pod uwagę możliwość jego rozbudowy, a więc etapowanie inwestycji, jednak w taki sposób, aby proporcje zewnętrzne biblioteki przed i po jego rozbudowie mogły zadowolić pięknem rozwiązania [...]. Jedno na pewno wiadomo: trzeba budować przewidując przyszły rozwój możliwie jak najtrafniej, wyciagając wnioski z dotychczasowych rozwiązań. A więc należy pamiętać nie tylko o pełnym wymiarze bryły budynku, ale również o tym, co będzie działo się wewnątrz 2 .

Budynek biblioteki powinien być zatem funkcjonalny i estetyczny. Według normatywu dotyczącego technicznego projektowania bibliotek publicznych z 1 marca 1975 roku wielkość biblioteki winna zależeć od liczby mieszkańców danego obszaru. Zatem w miejscu, w którym mieszka do 10 tys. osób (np. miasteczko) biblioteka powinna mieć $251-371 \mathrm{~m}^{2}$, z czego $55-90 \mathrm{~m}^{2}$ powinno przeznaczone być na wypożyczalnię, a 59-100 $\mathrm{m}^{2}$ - na czytelnię.

W Polsce bardzo często budynki bibliotek publicznych nie przypominają tych, o których mówi normatyw. Bardzo często zdarza się, że czytelnia i wypożyczalnia są w jednym pomieszczeniu. W swojej pamięci mam dziecięcy obraz miejsko-gminnej biblioteki, małej, ciasnej, ciemnej ze skrzypiąca podłoga. Miała ona pewien klimat tajemnicy - bardzo atrakcyjny dla dziecka, ale czy przyciagający też dorosłych? Patrząc z perspektywy czasu, gdybym dziś znów się do niej wybrała (bogatsza o doświadczenia z bibliotek znajdujących się w większych miastach i za granica), przeraziłby mnie brak odpowiedniego oświetlenia, mała powierzchnia i półki ustawione zbyt blisko siebie. Dziś biblioteka ta ma nowy budynek - jej ponowne otwarcie nastapiło w czerwcu $2012 \mathrm{r}$.

Nowo powstające biblioteki mają coraz większą powierzchnię, są zaprojektowane wewnątrz tak, aby zarówno pracownik jak i użytkownik byli zadowoleni. Według Głównego Urzędu Statystycznego, który co kilka lat przedstawia dane o powierzchni użytkowej bibliotek publicznych, sytuacja ciągle się polepsza. Często barierą jest jednak brak samodzielnego budynku. Według raportu „Biblioteki w Polsce”, przeprowadzonego w 2008 r. w wybranych bibliotekach publicznych w Polsce, blisko 90\% placówek miało budynek wspólny z inną instytucją - z ośrodkami kultury, szkołami, a nawet mieszkaniami prywatnymi. Powierzchnie $23 \%$ bibliotek uznane zostały za zdecydowanie za małe, a w $39 \%$ za nieco za małe.

Często zaletą bibliotek jest ich lokalizacja. Raport wykazał, że blisko 80\% książnic, w których przeprowadzono ankietę, ma swój budynek

\footnotetext{
${ }^{2}$ Cudnik Z.: Skarbnice wiedzy, Zakład Narodowy im. Ossolińskich, 1980, s. 55-57. 
w centrum miejscowości ${ }^{3}$. Czy jednak doskonała lokalizacja rekompensuje brak miejsca w czytelni i wypożyczalni? Budynki bibliotek, które właśnie powstają lub niedawno zostały otwarte mają znacznie większą powierzchnię i przemyślany układ, natomiast adaptacje starych budynków dają w tym zakresie znacznie mniejsze pole manewru. W wielu polskich bibliotekach publicznych (szczególnie w tych małych i w filiach) to relikt PRL. Biblioteki są szare, ciemne, niedostosowane do potrzeb dzieci i osób niepełnosprawnych. Niestety, nie wszystkie gminy stać na remont pomieszczeń, w wielu bibliotekach niewiele się robi, by było przyjemniej. Faktem jest, że biblioteki oraz kultura są niedoinwestowane i jeszcze wiele placówek musi poczekać na lepszy czas.

Należy stopniowo remontować stare budynki biblioteczne (głównie tych książnic, które nie mają szans na nowy gmach), aby stały się ciekawsze, a przede wszystkim bardziej funkcjonalne. Można to osiagnąć poprzez zlikwidowanie katalogu kartkowego i zastapienie go elektronicznym, czy utworzenie wypożyczalni czytników e-booków, z którym będzie można korzystać na terenie lokalu.

Jerzy Maj rozróżnia następujące rodzaje inwestycji bibliotecznych:

- budowę nowego obiektu według projektu indywidualnego,

- budowę nowego obiektu według projektu typowego lub powtarzalnego,

- adaptację budynku niebibliotecznego do funkcji bibliotecznych,

- modernizację, zwaną również remontem kapitalnym ${ }^{4}$.

W ostatnich latach w Polsce dokonywane są wszystkie z wyżej wymienionych inwestycji budowlanych w bibliotekach publicznych. Przedstawię po jednym przykładzie: generalnego remontu budynku oraz budowy nowego. Wybrałam biblioteki w różnych województwach: pierwsza to biblioteka w Myślenicach w województwie małopolskim, druga natomiast mieści się w Połańcu w województwie świętokrzyskim. Obydwa miasta łączy podobne środowisko społeczne. Są to miasta z jednym dużym zakładem przemysłowym oraz podobną sytuacją kulturalną - zarówno w Myślenicach jak i Połańcu znajduje się dom kultury i kino.

Przykładem nowo powstałej siedziby jest gmach Miejskiej Biblioteki Publicznej w Myślenicach. Dotychczasowa jej siedziba miała $400 \mathrm{~m}^{2}$ powierzchni i znajdowała się na pierwszym piętrze w kamienicy na myślenickim rynku. Nowy obiekt to $1400 \mathrm{~m}^{2}$. Na wypożyczalnię dla dorosłych przeznaczo-

${ }^{3}$ Raport Biblioteki w Polsce: sierpień 2008 [online]. Dostępny w Internecie: http://www.biblioteki.org/repository/PLIKI/DOKUMENTY/RAPORTY/Biblioteki_i_ bibliotekarze.pdf [data dostępu: 24.08.2012].

${ }^{4}$ Maj J.: Organizacja przestrzenna i wyposażenie biblioteki publicznej, Warszawa: Stowarzyszenie Bibliotekarzy Polskich, 1987, s. 149. 
no $135 \mathrm{~m}^{2}$, a na wypożyczalnię dla dzieci $-87,5 \mathrm{~m}^{2}$. W budynku znajduje się również czytelnia czasopism i czytelnia komputerowa oraz miejsce do odsłuchu audiobooków $\left(91 \mathrm{~m}^{2}\right)$. Dodatkowo na piętrze powstała czytelnia $\left(173 \mathrm{~m}^{2}\right)$. Pomieszczenia administracyjne zajmują $122 \mathrm{~m}^{2}$. Wewnątrz budynku znajduje się również winda, klimatyzacja i monitoring. Powstał on w sąsiedztwie Miejskiego Ośrodka Kultury i Sportu.

W starej siedzibie biblioteka miała tylko kilka komputerów, obecnie jest ich 12, dodatkowo na terenie nowego obiektu można bezpłatnie korzystać $\mathrm{z}$ bezprzewodowego Internetu. Prace budowlane zostały zakończone 14 maja. Bibliotekę otwarto dla czytelników 26 maja 2012 r. Budowa została sfinansowana z budżetu Miasta i Gminy Myślenice oraz z dotacji Ministerstwa Kultury. Dodatkowym atutem samego budynku jest to, iż jest atrakcyjny wizualnie. Jak ta zmiana wpłynie na wzrost czytelnictwa w Myślenicach dowiemy się dopiero porównując statystyki za pełny rok 2011 ze statystyką za cały rok 2013 (statystyka za rok 2012 nie będzie wiarygodna, ponieważ przez pewien czas biblioteka była zamknięta). Dotychczas na stronie internetowej biblioteki pojawiła się informacja, że: „w pierwszym miesiącu otwarcia biblioteki (trzy dni maja i czerwiec) czytelnicy ustanowili rekord - bibliotekę odwiedziło 6988 osób. Zapisało się do niej 668 nowych czytelników, wypożyczono 10402 książki, a z wypożyczalni i oddziału dla dzieci skorzystały 4804 osoby" ${ }^{5}$. Daje to nadzieję na jeszcze lepsze wyniki biblioteki.

Przykładem biblioteki, w której dokonano generalnego remontu, jest Miejsko-Gminna Biblioteka Publiczna w Połańcu. Mieści się ona w budynku Centrum Kultury i Sztuki na I piętrze (nie jest to jednak przeszkoda dla osób niepełnosprawnych, o czym napiszę później). Prowadzi ona wypożyczalnię i czytelnię dla dorosłych oraz specjalny oddział dla dzieci. W roku 2010 została uznana Biblioteką Roku województwa świętokrzyskiego. Prace remontowe związane były $\mathrm{z}$ modernizacją całego obiektu Centrum Kultury i Sztuki oraz współfinansowane przez Unię Europejską oraz Miasto i Gminę Połaniec. Fundusze na nowe meble biblioteka zdobyła sama w ramach programu Infrastruktura Kultury prowadzonego przez Ministerstwo Kultury i Dziedzictwa Narodowego ${ }^{6}$. Remont biblioteki trwał od 2009 do 2010 roku i objął wszystkie jej pomieszczenia. Na stronie internetowej placówki możemy zapoznać się ze szczegółowym opisem modernizacji:

Przede wszystkim wykonano nową instalację centralnego ogrzewania i instalację elektryczną oraz zamontowano nowoczesne oświetlenie. Poprowadzono

5 Miejska Biblioteka w Myślenicach [online]. Dostępny w Internecie www.biblioteka.myslenice.pl [data dostępu: 24 lutego 2013].

${ }^{6}$ Miejsko-Gminna Biblioteka Publiczna im. A. Mickiewicza w Połańcu [online]. Dostępny w Internecie: www.mgbp.polaniec.pl [data dostępu: 6.05.2012]. 
odrębną instalację do komputerów. Wykonano instalację przeciwpożarową i antywłamaniowa. Przeprowadzone instalacje poprawiły w znacznym stopniu warunki i bezpieczeństwo przechowywania i udostępniania zbiorów bibliotecznych, a zarazem poprawiły komfort pracy bibliotekarzy. Oprócz wymiany instalacji dokonano kilku zmian architektonicznych. Zlikwidowano bezużyteczny szyb windy towarowej wykonując strop. Miejsce to przeznaczono pod nowo wyposażoną serwerownię. Natomiast dzięki połączeniu dwóch małych korytarzy biblioteka uzyskała powierzchnię przeznaczoną na ekspozycje, która prowadzi odwiedzających do wypożyczalni i czytelni dla dorosłych lub oddziału dla dzieci. Po zamontowaniu przeszklonych drzwi wpuszczono do ciemnego korytarza więcej światła dziennego oraz uzyskano wrażenie przestrzenności całej biblioteki. Dzięki nim pomieszczenia wydzielone zostały bez utraty kontaktu wzrokowego czytelników i pracowników ${ }^{7}$.

Podczas remontu przejawiano dużą dbałość o komfort i samopoczucie czytelników, wprowadzając do biblioteki kilka funkcjonalnych udogodnień:

Jednym z celów zmian przeprowadzonych w bibliotece było stworzenie komfortowego miejsca dla wszystkich. Otwarta przestrzeń części przeznaczonej dla czytelników dorosłych mieści kilka stref użytkowania: wypożyczalnię i czytelnię z kącikiem prasowym oraz ze stanowiskami komputerowymi. Na wprost wejścia znajduje się wypożyczalnia wyposażona w funkcjonalną ladę biblioteczną z dwoma stanowiskami komputerowymi do obsługi czytelników. Użytkownikom umożliwiono wolny dostęp do półek. Poszukiwania książek warto zacząć od przejrzenia zawartości katalogu biblioteki, który jest dostępny na specjalnie do tego przeznaczonym komputerze. Po prawej stronie wydzielono Czytelnię, w której znajduje się kącik prasowy, stanowiska komputerowe z dostępem do Internetu oraz miejsca, przy których czytelnicy mogą swobodnie zagłębić się w lekturze książek z księgozbioru podręcznego. Za pomocą prostych środków udało się stworzyć ciepłą i przyjazną atmosferę. W pomieszczeniu wymieniono starą i zniszczoną wykładzinę na posadzkę żywiczną, która wraz z nową ciepłą kolorystyką ścian stanowi jedną, przyjazną dla odwiedzających, całość. Najważniejszymi gośćmi biblioteki są młodzi czytelnicy, dlatego wygląd i wyposażenie oddziału dla dzieci dostosowano do ich wieku i potrzeb. Zadbano o to, by urządzona dla najmłodszych przestrzeń stała się ciepła i przyjazna. Pomogły temu żywe barwy ścian oraz kolorowe, przyciągające uwagę dodatki (barwne wertykale, miękkie i bezpieczne pufy, element dekoracyjny w postaci kolorowych kół wkomponowanych w podłogę), które decydują o atrakcyjności miejsca ${ }^{8}$.

\footnotetext{
${ }^{7}$ Tamże.

${ }^{8}$ Tamże.
} 
Remont zwiększył zainteresowanie mieszkańców biblioteką, która jest teraz bardziej atrakcyjna, nowoczesna i przyjazna zarówno dla użytkownika pełno- jak i niepełnosprawnego. Przed biblioteką zamontowano podjazdy dla czytelników na wózkach inwalidzkich, a do samego pomieszczenia bibliotecznego znajdującego się na piętrze można dostać się za pomocą specjalnej windy przeznaczonej do transportu po schodach. Przeprowadzone inwestycje poprawiły również komfort pracy bibliotekarzy - udostępnianie i przechowywanie zbiorów jest teraz bezpieczniejsze. Zmiana wizerunku biblioteki wpłynęła pozytywnie przede wszystkim na liczbę czytelników. W roku 2009 było ich 1870, w roku kolejnym 1957 natomiast w roku 2011 już 2166. Wzrosła również liczba wypożyczeń z 28279 w 2009 roku do 40710 w roku 2011. Największy wzrost zaobserwować można jednak w liczbie odwiedzin, w roku 2009 było ich 14823, w roku kolejnym 17232, a w roku 2011 liczba ta sięgała już $40405^{9}$. Jak zatem z wyżej powiązanymi informacjami powiązać statystyki, że czytelnictwo spada? Moim zdaniem problem leży w tym, że biblioteki nie są dostosowane do obsługi każdego rodzaju czytelnika. A z jakimi barierami użytkownik może spotkać się z bibliotece? Patrząc na użytkownika niepełnosprawnego, główną barierą jest architektoniczne nieprzystosowanie obiektów do obsługi tej części społeczeństwa. Nie chodzi tylko o brak możliwości poruszania się osoby na wózku, ale również o niedostrzeganie problemów u osób niedowidzących lub niewidomych. Co prawda bibliotek, które oferują audiobooki lub książki pisane brajlem jest coraz więcej, ale problem tkwi głębiej, często osoby z wadami wzroku boją się przyjść do biblioteki, ponieważ potrzebują przewodnika nie tylko po tytułach książek, ale przede wszystkim na terenie lokalu. Istnieje również mnóstwo przeszkód dla osób zdrowych. Wśród nich wymienić można: brak przestrzeni w wypożyczalni i czytelni, brak odpowiednich sprzętów biurowych i komputerowych, niedostatek wygodnych miejsc do pracy w czytelniach, czy też nieprzyjemne, ciemne kolory pomieszczeń. Nie są to komfortowe warunki dla użytkownika.

O to, jak powinna wyglądać wzorcowa biblioteka publiczna, zapytałam kilku studentów kierunków ścisłych i humanistycznych uczelni znajdujących się w Krakowie ${ }^{10}$. Ich odpowiedzi były zbliżone. Na sam początek powiedzieli, że budynek powinien „rzucać się w oczy”, mieć ciekawy, intrygujący kształt architektoniczny. Już samo to wystarczyłoby, aby do niego zajrzeli. Ważnym punktem jest również to, żeby biblioteka miała oddział dla dzieci dostosowany dla ich potrzeb z oddzielną wypożyczalnią i czytelnią oraz część dla dorosłych również z osobnymi pomieszczeniami na wypożyczalnię, czy-

\footnotetext{
${ }^{9}$ Tamże.

${ }^{10}$ Rozmowa z 7 studentami krakowskich uczelni (AHG, UJ, PK) przeprowadzona w dniu 02.05.2012.
} 
telnię i mediatekę wyposażoną $\mathrm{w}$ bezpłatny dostęp do Internetu. Często wspominano o wolnym dostępie do zbiorów w czytelni oraz odpowiednich odstępach pomiędzy biurkami. Dla badanych ważne było też dobre oświetlenie miejsca pracy oraz niewysokie regały. Wzorcowa biblioteka publiczna powinna być wyposażona, zdaniem pytanych, w windy i szerokie korytarze ułatwiające poruszanie się osobom na wózkach inwalidzkich oraz matkom z dziećmi. powstawały pożądane były też specjalne kąciki z słuchawkami zwane czytelniami audiobooków.

Uczestnicy przeprowadzonych rozmów zwrócili również uwagę na aspekty wizualne wzorcowej książnicy, za istotny uznając kolor ścian jasny i ciepły, sprawiający wrażenie przyjemnego.

Wydaje się, że nie są to wielkie wymagania stawiane bibliotekom. Przebywając w Szkocji w lutym 2012 r. miałam przyjemność odwiedzić bibliotekę publiczną w małym miasteczku Annan - duży parterowy budynek z wszystkimi udogodnieniami dla osób niepełnosprawnych, w środku pomalowany na ciepły, jasny pomarańczowo-żółty kolor. Była to miła odmiana od ciagłej szarej pogody.

Czy zatem potrzebne są nam biblioteki marzeń? Chyba nie do końca. Samo odświeżenie wnętrza oraz życzliwość i fachowość personelu wpływa na wzrost liczby czytelników i to właśnie w tym kierunku powinny iść polskie biblioteki publiczne. Nastawienie na odbiorcę jest gwarancją sukcesu książnicy i winno ono przejawiać się nie tylko w obsłudze, ale także w odpowiednich warunkach lokalowych. Dzięki temu placówki staną się bardziej otwarte na nowe wyzwania, jakie stawia przed nimi technika i użytkownik.

\section{Bibliografia}

1. Biliński L.: Nowe obiekty bibliotek publicznych $w$ Polsce. W: Biblioteki jutra: nowa perspektywa organizacji przestrzennej i funkcjonalnej. [Red. meryt.: Jadwiga Chruścińska, Ewa Kubisz]. Warszawa: CEBID, 2001, s. 46-62

2. Cudnik Z.: Skarbnice wiedzy. Wrocław: Zakład Narodowy im. Ossolińskich, 1980. - ISBN 83-04-00273-6

3. Maj J.: Organizacja przestrzenna i wyposażenie biblioteki publicznej. Wyd. 2. Warszawa: Stowarzyszenie Bibliotekarzy Polskich, 1987. ISBN 83-00-00885-3

4. Raport Biblioteki w Polsce: sierpień 2008 [online]. Dostępny w Internecie: www.biblioteki.org/repository/PLIKI/DOKUMENTY/RAPORTY/Biblioteki_i_b ibliotekarze.pdf [data dostępu: 24.08.2012]

5. Statystyki i analizy biblioteczne Miejsko-Gminnej Biblioteki Publicznej w Połańcu za lata 2009, 2010, 2011 